ISSN:1308-8173

Geliş Tarihi: 31.01 .2020
E-ISSN: 1308-8505

Kabul Tarihi: 06.06.2021
YIL: 2021

Online Yayın: 02.08.2021

ÖZGÜN ARAŞTIRMA

Cilt: 36 Sayı: 1 Sayfa: $27-41$

Doi: 10.24988 /ije.202136103

\title{
Faaliyet Döngüsü ve Nakit Akış Döngüsünün Türkiye'deki Çimento Endüstrisinin Finansal Performansı Üzerindeki Etkileri
}

\author{
Turgut ÖZKAN ${ }^{1}$, Naime İrem DURAN² ${ }^{2}$ Özge DEMIRKALE ${ }^{3}$
}

Özet

Bu çalışma, Türkiye'de faaliyet gösteren ve Borsa İstanbul (BISTT)'da pay senetleri işlem gören çimento şirketinin firmalarının, faaliyet ve nakit döngüsünün firma ve sektör bazında etkilerini belirleyerek, bu etkilerin hem firma hem sektör bağlamında finansal performansı nasıl şekillendirdiğini ölçmeyi amaçlamaktadır. Çalışmada on dört çimento şirketinin firma ve sektör bazında faaliyet ve nakit döngüleri hesaplanmış ve her iki döngünün belirlenen performans kalemleri üzerine etkileri panel veri analizi yöntemiyle incelenmiştir. Analiz, 1997-2018 yıllarının üçer aylık periyodlarını kapsamaktadır. Analizden elde edilen sonuçlara göre işletme döngüsünü duran varlıklar ve finansal giderler etkilemektedir. Buna ek olarak, ilgili dönemde, ortalama stok ve ortalama ödeme süreleri finansal giderler üzerinde anlamlı bir etkiye sahiptir.

Anahtar kelimeler: Faaliyet Döngüsü, Nakit Akış Döngüsü, Çimento Endüstrisi, Finansal Performans Jel Kodu: $G, M, C 23$

\section{Effects of The Operating Cycle and Cash Conversion Cycle on Financial Performance of The Turkey's Cement Industry}

\begin{abstract}
This study aims to determine the effects of operating and cash conversion cycle of cement companies operating in Turkey and trading shares in Borsa Istanbul (Bist) on the basis of firms and sectors and to measure how these effects shape financial performance in the context of both firms and sectors. In the study, operating and cash conversion cycle of fourteen cement companies on the basis of firm and sector were calculated and the effects of both cycles on the identified performance items were examined by panel data analysis. The analysis include the quarterly periods of 1997-2018. According to the results obtained from the analysis, fixed assets and financial expenses affect the operating cycle. In addition, in the corresponding period, average stock and average pay times have a meaningful impact on financial expenses.
\end{abstract}

Keywords: Operating Cycle, Cash Conversion Cycle, Cement Industry, Financial Performance.

Jel Codes: $G, M, C 23$

\section{GíRiş}

Firmalar açısından her bir birim ürün için harcanan toplam faaliyet süresi son derece büyük önem taşımaktadır. Bu sürenin uzunluğu veya kısalığının firmanın sahip olduğu kaynakların verimli kullanımı ile ilgili olmasının yanı sıra nakit giriş ve çıkışlarının zamanlamasını, firmanın nakit yaratma kabiliyetini de belirlemesi açısından firma değerliliği üzerindeki etkisi yüksektir. Yönetimin operasyonel başarısını ölçmede kullanılabilecek bu süre ya da süreç, firmanın likidite yapısını, fon yaratma gücünü, kaynak gereksinimini, kısaca finansal performansını ya da birim üretim için harcadığı kaynağı doğrudan etkilemektedir.

Faaliyet Döngüsü (FALD); girdi temini ve girdinin firma stoklarına alınması, girdinin üretim sürecinden geçirilerek satışa hazır hale getirilmesi, vadeli temin edilen girdi bedelinin tedarikçilere ödenmesi, ürünün müşteriye satılarak teslim edilmesi ve stoklardan çıkarılması, ürün bedelinin satış politikasına

ATIF ÖNERİSí (APA): Özkan, T., Duran, N.İ., Demirkale, Ö. (2021). Faaliyet Döngüsü ve Nakit Akış Döngüsünün Türkiye'deki Çimento Endüstrisinin Finansal Performansı Üzerindeki Etkileri. İzmir İktisat Dergisi, 36(1), 27-41. Doi:10.24988/ije.202136103

${ }^{1}$ Prof. Dr., Doğuş Üniversitesi, Rektör, EMAIL: tozkan@dogus.edu.tr ORCID:0000-0002-5017-0257

${ }^{2}$ Dr. Öğr. Üyesi, Beykent Üniversitesi, İktisadi ve İdari Bilimler Fakültesi, Sermaye Piyasası Bölümü EMAIL: iremkosan@beykent.edu.tr ORCID: 0000-0002-8953-2171

${ }^{3}$ Dr. Öğr. Üyesi, İstanbul Aydin Üniversitesi, İktisadi ve İdari Bilimler Fakültesi, İşletme Bölümü

EMAIL: ozgedemirkale@aydin.edu.tr ORCID: 0000-0002-4227-3934 
uygun olarak müşteriden tahsili aşamalarından oluşmaktadır. Bir ürünün ya da firmanın faaliyet döngüsü firmanın üretim biçimine, ürünün özelliklerine, ürüne olan talebe, satış ve girdi bedelinin ödeme koşullarına, sektörel yapıya ve piyasa koşullarındaki değișmeye bağlı olarak farklılaşmaktadır.

Faaliyet döngüsü süresi firmanın faaliyet konusunu oluşturan bir ürünün firmaya hem kaydi (muhasebesel) hem de fiziksel (stok) olarak girişinden, kaydi ve fiziksel olarak çıkışına kadar olan süreci ve bu sürece ilişsin tüm nakit hareketlerini ifade etmektedir. Dolayısı ile firmanın üretim konusuna bağlı olarak, faaliyet döngüsünün içerisinde tedarik, stok, üretim, satış, tahsilat ve borç ödeme politikaları yer almaktadır. Bu süre ne kadar kısa olursa, firmanın likidite yapısı o kadar güçlü olmaktadır. Böylece firma likidite sorunu olasılığını azaltarak, başka bir tanımlama ile finansman maliyetlerini minimize ederek, daha yüksek kârlılık düzeylerine ve rekabet gücüne ulaşma olanağı yaratabilmektedir. Sürenin uzaması ise belirtilen politikaların etkin kullanılamadığı, firmanın süreçlerinin iyi yönetilemediği, kaynaklarının optimize edilemediği ve düşük verimlilikle çalışıldığı anlamına gelmektedir.

Bir firmanın faaliyet döngüsünü etkileyen en önemli unsur faaliyetlerine ilişkin verimlilik düzeyidir. Verimlilik, faaliyet döngüsü süresi konusunda firmayı rakiplerinden ayıran, ön plana çıkaran ve süreyi kısaltarak avantaj yaratan bir faktördür. Verimlilik ayrıca malın stokta kalma ve üretim süresini kısaltarak hem stok ve üretim maliyetlerinin düşmesini hem de faaliyet döngüsünün kısalmasını sağlar.

Faaliyet döngüsü zaman içinde değişime uğrayabilmektedir. $\mathrm{Bu}$ nedenle faaliyet döngüsünün bir yönetimin başarı ölçütü olarak kullanılması dinamik bir bakış açısını gerektirmektedir. Başka bir deyișle değișen koşullara göre firmanın faaliyet döngüsü her seferinde yeniden hesaplanmall, faaliyet döngüsü ölçütü güncel tutulmalı ve geçmişteki trend güncel verilerle analiz edilmelidir. Elde edilen sonuçlar sektör ortalaması ile ve rakip firmalarla karşılaștırılmalı, ulașılan bulgulara göre süreci iyileştirecek revizyonlar yapılmalı, firmanın gelecekteki performansının tahmini sağlanmalıdır.

Faaliyet döngüsünün fon akışı açısından iki önemli belirleyicisi bulunmaktadır:

1) Girdi bedelinin ödenmesiyle oluşan nakit çıkıșı,

2) Satış bedelinin tahsilatıyla oluşan nakit giriși.

Ticari borçların tedarikçilere ödenmesinden, satış bedelinin müşterilerden tahsiline kadar olan aradaki süre Nakit Döngüsü: NAKD olarak adlandırılmaktadır. Faaliyet döngüsünde önemli olan husus, nakit giriş ve çıkışlarının önceliği ya da nakit döngüsü pozisyonudur. Bu nakit akış pozisyonu firmanın nakit yapısı ve gücü üzerinde belirleyici bir etkiye sahiptir. Nakit akış önceliği firmanın faaliyet gösterdiği sektöre, ürünün özelliklerine, üretim ve satış olanaklarına göre farklılık göstermektedir. Bazı firmalarda nakit çıkışı, bazı firmalarda ise nakit girişi önce gerçekleşebilmektedir. Bu iki nakit akış pozisyonuna ya da hangi nakit akışının önce gerçekleştiğine göre Nakit Döngüsü'nün iki farklı çeşidi bulunmaktadır:

- Pozitif Nakit Döngüsü: Tipik özelliği faaliyet süreci içerisinde nakit çıkışının nakit girişinden önce gerçekleşmesidir. $\mathrm{Bu}$ tür firmalarda nakit döngüsü süresinin firma kaynakları (yabancl kaynaklar veya özkaynak) ile finansmanı gerekliliği ortaya çıkmaktadır. Böyle bir süreç firma için ek fon (kaynak) gerektirmektedir. Pozitif nakit döngüsüne sahip bir firmanın finansman maliyetleri artmakta, kâr marjı daralmakta ve rekabet olanakları kısıtlanmaktadır.

- Negatif Nakit Döngüsü: Firmanın nakit çıkışlarının nakit girişlerinden sonra gerçekleşmesidir Böyle bir faaliyet sürecine sahip olan firmalar her faaliyet sürecinde negatif nakit döngüsü süresi kadar kullanabileceği ve üzerinden bir getiri sağlayabileceği fazla fon elde etmektedirler. $\mathrm{Bu}$ fonun yarattığı getiri ise firmanın kâr 
marjını, rekabet gücünü ve piyasa değerini artırıcı bir katkı yapmaktadır.

Firmaların pozitif nakit döngüsünün minimize edilmesi ve negatif nakit döngüsünün firma lehine daha da iyileștirilmesi finansal etkileri açısından büyük önem taşımaktadır. Buna yönelik iyileştirme stratejilerinin süreklileștirilmesi firmaların sektörel etkinliğini, büyüme potansiyelini ve firma değerliliğini artırıcı çabalarının rekabetçi sonuçlarını kolaylaştırmaktadır.

Pozitif ve negatif faaliyet süreci şekilleri irdelendiğinde nakit döngüsünü iyileștirmek, daha rekabetçi hale getirmek için izlenebilecek üç temel stratejinin olduğu görülmektedir:

- Stokların Ortalama Tüketilme Süresi (SOTS)'nin Kisaltılması,

- Alacakların Ortalama Tahsil Süresi (AOTS)'nin Kisaltılması,

- Borçların Ortalama Ödeme Süresi (BOÖS)'nin Kısaltılması.

Görüldüğü gibi; Faaliyet Döngüsü ve Nakit Döngüsü firmaların kârlılığı ve finansal performansı üzerinde son derece büyük bir etki yaratabilecek bir süreçtir. Bu finansal etkinin belirlenmesi hem firmanın performansının ölçülmesi hem de gelecek potansiyelinin saptanması açısından değerli bilgiler içermektedir.

Bu çalışmanın amacı; Faaliyet Döngüsü ve Nakit Döngüsü 'nün firma ve sektör bazında etkilerini belirlemek, bu etkilerin finansal performansı nasıl şekillendirdiğini irdelemektir. Türkiye Çimento Sektörü özelinde yapılan analizde, çimento sektöründe faaliyet gösteren firmaların ve sektörün Faaliyet Döngüsü ve Nakit Döngüsü hesaplanmış, her iki döngünün ve finansal tabloların belirlenen performans kalemlerinin karşıllklı etkileri ekonometrik testlerle belirlenmiştir.

Literatürde faaliyet ve nakit döngülerini baz alan çalışmalar bulunmakla birlikte, çalışmamız; döngülerin firmaların bilanço ve gelir tabloları üzerindeki iki yönlü etkilerini de analiz etmesi açısından katkı sağlayacak niteliktedir. Çalışma; giriş, literatür taraması, kullanılan model ve yöntem, veriler, analiz ve bulgular ile sonuç kısmından oluşmaktadır.

\section{LITERATÜR TARAMASI}

Konuya ilişkin yapılan çalışmaların genellikle kısa dönemli analizler içerdiği anlaşılmaktadır. NAKD süreleri ile araştırmacıların seçtiği finansal tablo kalemleri ve firma performansını simgelediği düşünülen parametreler arasındaki ilişkilerin yönü ve boyutunun irdelendiği araștırmaların, NAKD bazında ve sektörel karşılaştırmalarda yoğunlaştı̆̆ görülmektedir.

Farris, Hutchison ve Hasty (2005), imalat ve hizmet sektörlerinde faaliyet gösteren 5884 firmanın 1987-2001 dönemi finansal tablo verilerini kullanarak yaptıkları ampirik çalışmada, iki sektörün NAKD süreleri arasındaki farklılığı incelemişler. Çalışmada hizmet sektörünün imalat sektörüne göre daha düşük NAKD süresine sahip olduğunu saptamışlardır.

Ramachandran ve Janakiraman (2009), Hindistan'da kağıt sanayinde faaliyet gösteren firmaların 1997-1998 ve 2005-2006 dönemini, performans, fayda ve etkinlik endeksleri kapsamında incelenmişlerdir. Bunun için, özellikle NAKD başta olmak üzere çeşitli rasyoların FVÖK (Faiz ve Vergi Öncesi Kâr, EBIT: Earnings Before Interest and Taxes) ve çalışma sermayesi üzerindeki etkileri ekonometrik bir analize tabi tutulmuş ve kağıt firmalarının çalışma sermayelerini iyi yönettikleri sonucuna ulaşılmıştır.

Mohama ve Saad (2010), Malezya borsasında yaptıkları çalışmada 2003-2007 döneminde 172 firmanın NAKD, cari oran, dönen varlık/toplam varlık, Kisa Vadeli Yükümlülükler/Toplam Varlıklar oranlarının işletme sermayesine, Tobin q, Aktif Getisi (ROA: Return on Assets) ve Duran varlık kârlılı̆̆ (ROIC: Return on Invested Capital) oranlarının işletme performansına etkisini irdelemişlerdir. Nakit, alacak, stok gibi işletme sermayesi değişkenleri ile işletmenin performansı arasında negatif ilişki bulmuşlardır.

Ebben ve Johnson (2011), çalışmalarında ABD'de faaliyet gösteren 879 adet imalat ve 


\section{T. ÖZKAN- N.I. DURAN - Ö.DEMIRKALE}

833 adet KOBİ (Küçük ve Orta Boy İşletmeler, SME: Small and Medium Sized Enterprises) kapsamındaki perakende firmasının NAKD'nün likidite, yatırılan sermaye ve performansları arasındaki ilişkileri incelemişler ve aralarında güçlü bir korelasyonun varlığını saptamışlardır.

Nobanee, Abdullatif ve AlHajjar (2011), Tokyo Borsası'nda işlem görmekte olan farklı sektörlerden 2.123 firmanın 1990-2004 dönemi finansal tablolarından hesaplanan NAKD sürelerini, çalışma sermayesi ve kârlılık arasındaki ilişki GMM (Generalized Method of Moment) yöntemini kullanarak analiz etmişlerdir. Tüketim malları ve hizmet sektörü dışında diğer tüm sektörlerde NAKD süresi ile kârlılık arasında güçlü bir negatif ilişkinin olduğu sonucuna varmışlardır. Mathuva (2014), Kenya'da finansal olmayan kurumları kapsayan benzer bir çalışmada aynı sonuca ulaşmıştır.

Attari ve Raza (2012), Pakistan borsasında işlem gören çimento, kimya ve gida sektöründe faaliyet gösteren firmaların 2006-2010 yılları arasındaki finansal tablolarından NAKD ile firma büyüklügü ve kârlılığı arasındaki ilişkiyi araştırmışlar, otomobil sektörünün NAKD süresinin diğerlerine göre daha uzun olduğu ve NAKD süresi ile işletme büyüklüğü ve kârlılık arasında negatif bir ilişkinin bulunduğu sonucuna varmışlardır. Teruel ve Solano (2007), İspanya'daki KOBİler üzerine yaptıkları ampirik çalışmada benzer bir sonuca ulaşmışlardır.

Tusek, Percevic, Hladika (2014), Croatia'da 2009-2012 dönemi hotel endüstrisinde NAKD ile kârlılık arasındaki ilișkiyi irdelemișlerdir. NAKD ile VÖK (Vergi Öncesi Kâr, EBT Earnings Before Taxes), ROA ve ROE (Kaynak Getirisi, Return on Capital) arasında istatistiksel olarak anlamlı doğrusal bir ilişkinin olmadığını saptamışlardır.

Yazdanfar ve Öhman (2014), İsveç'de metal, restaurant, perakende, toptan alanlarda faaliyet gösteren KOBİlerin 2008-2011 dönemi finansal tablolarından yararlanılarak hazırlanan NAKD'lerinin kârlılıkları üzerindeki etkileri panel veri analizine tabi tutmuşlar ve NAKD'nün kârlılık üzerinde etkili olduğu sonucuna varmışlardır. Ayrıca çalışmalarında firma yaşı, hacmi, üretim alanı gibi faktörlerinde kârlılık üzerinde etkili olduğunu ileri sürmüşlerdir.

Talonpoika et al. (2014), Helsinki Stock Excahange'de işlem gören ve on farklı sektörde faaliyet gösteren 121 firmanın 2010-2012 dönemi NAKD süreleri ile peşin ödeme süresinin eklendiği modified NAKD sürelerinin çalışma sermayesi (Working Capital) üzerine etkilerini analiz etmişlerdir. NAKD'nün, önemli ölçüde avans ile çalıșan firmaların çalıșma sermayelerinin gerçek verimliliğini ölçmede etkili bir araç olduğunu ileri sürmüşlerdir.

Gill, Biger ve Obradovich (2015), çalışmalarında New York borsasında işlem gören ve imalat sektöründe faaliyet gösteren 189 firmanın, 2009-2013 dönemi için, yönetim kurullarında bağımsız yönetici bulunması ile NAKD süresi arasında bir ilișkinin olup olmadığını irdelemişler ve bu tür firmaların Stokların Ortalama Tüketilme Süresi (SOTS) ile NAKD sürelerinin daha kısa olduğunu saptamışlardır.

Dorisz ve Andrea (2015), Macaristan'da yüksek özkaynağa, hasılata ve ürün çeșitlendirmesine sahip günlük ürün üreten firmalarla ilgili yapılan ve finansal tablolara dayalı ampirik çalışmalarında, küresel krizin finansal pozisyonlarında ve rekabet güçlerinde yarattığ değişimi irdelemişler ve NAKD'deki azalmanın işletme sermayesi etkinliğini iyileștirdiğini kanıtlamışlardır.

Lyngstadaas ve Berg (2016), Norveç'de 20102013 dönemi SME firmalarının çalışma sermayesi yönetimlerinin kârlılıklarına etkilerini analiz etmişlerdir. NAKD, ROIC, ROA gibi bağımsız değişkenler kullanılarak, panel veri analizinden yararlanılmıştır. Bulgular NAKD süresi ile kârlılık arasında negatif bir ilişki olduğunu göstermiştir.

Türkiye'ye ilişkin yapılan çalışmalar, genelde, kısa dönemli olup, NAKD sürelerinin sektörel bazda hesaplanmasına ve karşılaştırılmasına 
dayanmaktadır. NAKD'nün ve parametrelerinin finansal performansa etkilerinin araştırıldığ çalışmaların son derece sınırlı olduğu görülmektedir.

Korkmaz ve diğerleri (2008), BİST'de işlem gören 15 adet çimento firmasının 2003-2007 dönemi yıllık finansal tablolarını kullanarak 8 adet finansal rasyo hesaplamış ve panel veri analizi yöntemi ile bu rasyoların firmaların aktiflerine ve EBIT'e etkilerini analiz etmişlerdir. Çalışmada, İşletme Sermayesi Devir Hızı (Net Working Capital Turn Over) ve Faiz Karşılama Oranı (Interest Solvency Rate) dışındaki diğer rasyoların etkisi istatistiki olarak anlamlı bulunmuştur.

Sakarya (2008), BİST'de işlem gören KOBİ tanımındaki 43 firmanın 2003-2006 yılları finansal tablolarından nakit yönetim etkinliklerini araştırmış, son dönemde NAKD'nün önemli ölçüde arttığını bulmuş ve artışın sebebini nakit gereksiniminin yükselmesi olarak belirtmiştir. Oysa, tersine, NAKD süresinin uzamasının nakit gereksiniminin artmasına yol açması beklenmelidir.

Karadeniz (2012), turizm işletmelerinin 20022010 dönemi NAKD sürelerini incelemiş, sektörün negatif NAKD'e sahip olduğunu saptamış ve NAKD'e etki eden en önemli parametrenin AAI (Average Age of Inventory) olduğu sonucuna varmıştır.

Çakır (2013), BİST'de işlem gören imalat sektöründeki 52 firmanın 2000-2010 dönemi NAKD'nün işletme kârlılığına etkisini araştırdığı çalışmasında, diğer sektörlerin aksine imalat sanayinde NAKD süresi ile kârlılık arasında pozitif bir ilişki saptamış olup, bu sonucun literatüre uygun olduğunu söylemek mümkün değildir.

Ege, Topaloğlu ve Karakozak (2016), BİST-50 endeksinde ișlem gören 27 firmanın 20052013 dönemindeki finansal tablolarından NAKD sürelerini hesaplamışlar ve araștırma kapsamındaki firmaların negatif NAKD'e sahip olduklarını ileri sürmüșlerdir.

\section{MODEL, VERİ VE YÖNTEM}

Herhangi bir firma için faaliyet ve nakit döngülerini, gerekli sağlıklı verilerin elde edildiği herhangi bir zaman kesiti için hesaplamak mümkündür. Dolayısı ile hesaplanan döngüler belirli bir tarih kesiti itibarı ile firmanın pozisyonunu ya da nakit akış durumunu vermektedir. Bir firmanın nakit akıș pozisyonunu saptamak için önce FALD yapısı belirlenmeli, daha sonra NAKD hesaplanmalıdır. FALD ve NAKD'ünü oluşturan parametreler ve bu parametrelerin firmanın finansal performansı üzerindeki karşılıklı etkileşimi ya da çalışmanın modeli Şekil: 1'de verilmiş, Tablo: 1'de her bir parametrenin açılımı gösterilmiştir.

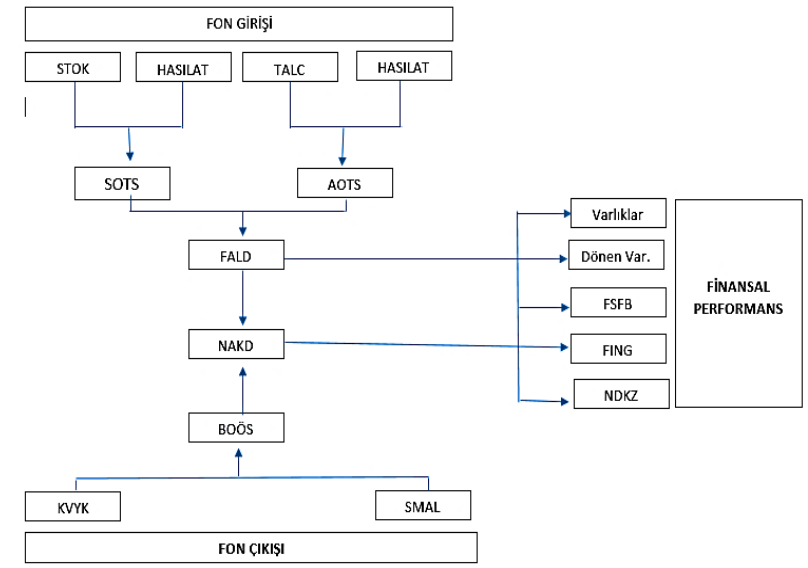

Şekil 1: Faaliyet Döngüsü ve Nakit Döngüsünün Finansal Performans Üzerindeki Etkisi.

Tablo 1: Model'de Yer Alan Parametreler

\begin{tabular}{|l|l|l|l|}
\hline $\begin{array}{l}\text { Sto } \\
\text { k }\end{array}$ & Stoklar & $\begin{array}{l}\text { KV } \\
\text { YK }\end{array}$ & $\begin{array}{l}\text { Kı̈a } \\
\text { Yükümlülükler }\end{array}$ \\
\hline HS & Hasılat (Net Satışlar) & SM & Satışların Maliyeti \\
LT & & AL & \\
\hline TA & Ticari Alacaklar & VA & Varlıklar \\
LC & & RL & \\
\hline SO & Stokların Ortalama & DV & Dönen Varlıklar \\
TS & Tüketilme Süresi & AR & \\
\hline AO & Alacakların Ortalama & FSF & Finans Sektörü \\
TS & Tahsil Süresi & B & Faaliyetlerinden Borçlar \\
\hline FAL & Faaliyet Döngüsü & FIN & Finansman Giderleri \\
D & & G & \\
\hline NA & Nakit Döngüsü & ND & Net Dönem Kâr Zararı \\
KD & & KZ & \\
\hline BO & Borçların Ortalama & DB: & Dönemin Başlangıcı \\
ÖS & Ödeme Süresi & & \\
\hline DS: & Dönemin Sonu & & \\
\hline
\end{tabular}

Araștırma 1997-2018 yıllarının çeyrek dönemleri olmak üzere 22 yılı ve 88 dönemi kapsamaktadır. Analiz dönemi içinde bilanço ve gelir tablosu süreklilik gösteren 14 çimento 


\section{T. ÖZKAN- N.I. DURAN - Ö.DEMIRKALE}

şirketinin bilanço ve gelir tabloları www.kap.gov.tr sitesinden alınarak, kullanılmıştır. Çimento şirketleri: Adana Çimento A.Ş., Afyon Çimento A.Ş., Akçansa Çimento A.Ş., Batıçim A.Ş., Bolu Çimento A.Ş., Bursa Çimento A.Ş., Çimbeton A.Ş., Çimentaş A.Ş., Çimsa Çimento A.Ş., Göltaş A.Ş., Konya Çimento A.Ş., Aslan Çimento A.Ş., Mardin Çimento A.Ş. ve Ünye Çimento A.Ş.'dir.

Şekil: 1'e göre FALD ve NAKD'nün üç temel bileşeni bulunmaktadır:

- Girdi alımından ürünün müşteriye satışına kadar olan süre: SOTS,

- Ürünün müşteriye satışından tahsiline kadar olan süre: AOTS,

- Girdinin tedarikçilerden satın alınmasından girdi bedelinin ödenmesi ya da nakit çıkışının yapılması arasında kalan süre: BOÖS.

Belirtilen ayırıma ve tanımlamalara göre FALD ve NAKD'ü aşağıdaki şekilde ifade edilmiştir:

FALD $=$ SOTS + AOTS

NAKD $=$ FALD - BOÖS

FALD $=$ BOÖS + NAKD

NAKD $=($ SOTS + AOTS $)-$ BOÖS

FALD ve NAKD eşitliklerinin üç temel parametresi olan SOTS, AOTS ve BOÖS süreleri gün olarak aşağıdaki denklemler kullanılarak hesaplanmıștır:

SOTS $=\frac{\text { ort.Stok }(365)}{\text { HSLT }} \quad$ AOTS $=\frac{\text { Ort.TALC (365) }}{\text { HSLT }}$

$B O O ̈ S=\frac{\operatorname{OrtKVYK}(365)}{\text { SMAL }} \quad$ ORT ALAMA $=\frac{D B+D S}{2}$

Araştırma üç adımda gerçekleştirilmiştir:

İk Adım: Her şirketin bilanço ve gelir tablosu ile ilgili verileri toplandı: Bilanço: 1. Toplam Varlıklar (Aktifler), 2. Dönen Varlıklar, 3.Stoklar, 4.(Kısa Vadeli) Ticari Alacaklar, 5.Kısa Vadeli Borçlar, 6.Kısa Vadeli Finansal Borçlar, 7.Net Dönem Kârı Zararı. Gelir Tablosu: 1.Net Satışlar(Hasılat), 2.Satılan Malın Maliyeti (Satışların Maliyeti), 3.Finansman Giderleri

İkinci Adım: Her şirket için 1) SOTS, 2) AOTS, 3) BOÖS, 4) FALD, 5) NAKD hesaplandı.
Ücüncü Adım: 1) SOTS - NAKD, 2) AOTS NAKD, 3) BOÖS - NAKD, 4) NAKD -Varlıklar, 5) NAKD -Dönen Varlıklar, 6) NAKD -Finansal Borçlar, 7) NAKD -Finansman Giderleri, 8) NAKD -Net Gelir arasındaki karşılıklı korelasyonları ölçmek için e-views de panel data analizi yapıldı.

Çalışma için denklemleri oluşturan değişkenlerle tüm modeller tahmin edilmiş, anlamlı modeller yorumlanmıştır. Çalışmada, panel veri analizine başlamadan önce, serilere seriler arasında yatay kesit bağımlılığını araştırmak amacı ile Pesaran (2004)'ün geliştirdiği CD testi ve sonrasında durağanlık analizi yapılmıștır. Test istatistiği;

$\mathrm{CD}=\sqrt{\frac{2 T}{N(N-1)}}\left(\sum_{i=1}^{N-1} \sum_{j=i+1}^{N} \rho_{i j}\right)$

şeklinde hesaplanmaktadır.

Peseran (2008) tarafından geliştirilen sapması düzeltilmiş test istatistiği ise;

$$
L M_{a d j}=\sqrt{\frac{2 T}{N(N-1)}}\left(\sum_{i=1}^{N-1} \sum_{j=i+1}^{N} \frac{(T-k) \hat{p}_{i j}^{2}-\mu_{T i j}}{u_{T i j}}\right)
$$

şeklindedir. Bu testte sıfır hipotezi yatay kesit bağımsızlığını ifade etmektedir. Eşitlikteki $\mathrm{k}$ değeri açıklayıcı değişken sayısını gösterirken,

$(T-k) \hat{\rho}_{i j}^{2}$ büyüklüğünün ortalaması $\mu_{T i j}$ ve standart hatası $u_{T i j}$ ile tanımlanmaktadır. $\mathrm{Bu}$ testte sıfır hipotezi yatay kesit bağımsızlığını ifade etmektedir. (Güriş ve diğerleri, 2018, s.90). Serilerde, yatay kesit bağımlılığı incelendikten sonra bağımlılık var ise bunu dikkate alan ikinci kușak panel birim kök testlerinden Pesaran Panel Birim kök testi yapılmıştır. Basit CADF regresyonu $\Delta Y_{i t}=\alpha_{i}+\rho_{i}^{*} Y_{i t-1}+d_{0} \hat{Y}_{t-1}+d_{1} \Delta \bar{Y}_{t}+\varepsilon_{i t}$ şeklinde tanımlanabilmektedir. Burada $\hat{Y}_{t}$, tüm $\mathrm{N}$ gözlemlerinin zaman $\mathrm{t}^{\prime}$ ye göre ortalamasıdır. Test için sıfır hipotezi:

$$
H_{0}: \rho^{*}=0 \text {, bütün /kesit birim için }
$$

olarak oluşturulurken, alternatif hipotezler, 
$H_{1}: \rho^{*}<0, \mathrm{i}=1,2 \ldots \mathrm{N}, \quad$ biçiminde tanımlanır.

Modelde otokorelasyon var ise CADF( kesitsel bağlılık durumunda geniş̧letilmiş Dickey Fuller) modeli aşağıdaki gibi genişletilebilmektedir.

$\Delta Y_{i t}=\alpha_{i}+\rho_{i}^{*} Y_{i t-1}+d_{0} \hat{Y}_{t-1}+\sum_{j=0}^{p} d_{j+1} \Delta \overline{Y_{t-j}}+\sum_{k=1}^{p} c_{k} \Delta Y_{i, t-k}+\varepsilon_{i t}$ CIPS $=\frac{1}{N} \sum_{i=1}^{N} C A D F_{i}$

$\mathrm{Bu}$ formülle hesaplanan değerler, çeşitli T ve $\mathrm{N}$ değerlerine göre hesaplanan tablo değerleri ile karşılaştırılarak seride birim kök varlığına karar verilir (Güriş vd., 2018, s.309).

\subsection{Panel Veri Modelleri}

Genel olarak panel veri modeli aşağıdaki şekilde gösterilmektedir.

$$
Y_{i t}=\beta_{0 i t}+\beta_{1 i t} X_{i t}+u_{i t} \mathrm{i}=1,2,3 . . \mathrm{N} \mathrm{t}=1,2,3, . \mathrm{T}
$$

Burada Y bağımlı değişken, $X$ bağımsız değişken, $\beta_{0 i t}$ sabit parametre, $\beta_{1 i t}$ eğim parametresi, $u_{i t}$ ise hata terimidir. Sabit etkili panel veri modeli: $Y_{i t}=\beta_{0 i}+\sum_{k=1}^{K} \beta_{k} X_{i t}+u_{i t}$ $\mathrm{i}=1,2,3 . . \mathrm{N} \quad \mathrm{t}=1,2,3, . . \mathrm{T}$ şeklinde gösterilir. Sabit etkiler modelinde eğim parametresi sabit, sabit parametre ise içinde birim etkisi barındırdığından birimden birime değişmektedir. Sabit etkiler modelinde $\mu$ i sabit ve hata terimleri sıfır ortalamalı ve sabit varyanslı kabul edilir. Rassal etkiler modelinde, birim etkiler ile açıklayıcı değişken arasında ilişki olmadığı kabul edilir ve birim etkiler hata teriminin bir bileșeni olarak ele alınır. Rassal etkili panel veri modeli: $Y_{i t}=\beta_{0}+\beta_{1} X_{1 i t}+\beta_{2} X_{2 i t}+\cdots+\beta_{k} X_{k i t}+v_{i t}$

şeklinde ifade edilir. Rassal etki modelinde birim etki tesadüf olduğundan hata terimi içinde yer alır. Bu sebepten dolayı rassal etkiler modeli hata bileșenleri modeli olarak bilinir (Güriş ve İmre, 2018, s.38). Çalışmada model tahminleri yapıldıktan sonra, hangi modelin etkin olduğunu belirlemek amacı ile Hausman testi yapılmıştır.

\subsubsection{Hausman Testi}

Hausman testi rassal etkili model ve sabit etkili model seçiminde sıklıkla kullanılan bir testtir. Açıklayıcı değişkenler ile birim etki arasında korelasyon var ise sabit etkiler modeli, yok ise rassal etkiler modeli daha etkindir. Testin hipotezleri:

$H_{0}: E\left(u_{i t} / X_{i t}\right)=0$, Rassal etkiler modeli geçerlidir.

$H_{1}: E\left(u_{i t} / X_{i t}\right) \neq 0$, Sabit etkiler modeli geçerlidir şeklindedir. Hausman istatistiği $\xi_{H}=\left(\hat{\beta}_{F E}-\hat{\beta}_{R E}\right)^{\prime}\left[\hat{V}\left(\hat{\beta}_{F E}\right)-\hat{V}\left(\hat{\beta}_{R E}\right)\right]^{-1}\left(\hat{\beta}_{F E}-\hat{\beta}_{R E}\right)$ şeklinde hesaplanır. hipotezinin kabul edilmesinde hem sabit etkiler modeli hem rassal etkiler modeli tahmincileri tutarlı olacaktır (Güriş vd., 2018, s.72).

\subsubsection{Panel Veri Modellerinde Varsayım Testleri, Sabit Varyans Varsayımı}

Değiștirilmiș Wald Testi: Sabit etkiler modelinde kullanılan Wald istatistiği her bir birimin varyansının panel ortalamasına eşit olduğu boş hipotez: $\quad H_{0}: \sigma_{i}^{2}=\sigma^{2}(\mathrm{i}=1,2 \ldots . . \mathrm{N}$ olmak üzere) Değișen varyans yoktur şeklindedir ve $W=\sum_{i=1}^{N} \frac{\left(\hat{\sigma}_{i}^{2}-\sigma^{2}\right)^{2}}{V_{i}}$ eşitliği ile test edilmektedir. İstatistik değerinin elde edilmesi için panel veri birimi varyans değeri hesaplanmaktadır. Hesaplanan varyans değeri düzeltme işleminden sonra: $V_{i}=T_{i}^{-1}\left(T_{i}-1\right) \sum_{t=1}^{T_{i}}\left(e_{i t}^{2}-\sigma_{i}^{2}\right)^{2} \quad$ eşitliği ile tanımlanarak test sürecine katılmaktadır. Birim sayısı serbestlik derecesinde Ki-Kare dağılımı ile test sonlandırılmaktadır.

Levene-Brown ve Forsythe Testi: Tesadüfi etkiler modelinde hata terimlerini eş varyans varsayımını test etmek için Levene(1960), Brown ve Forsythe(1974) testleri kullanılmaktadır. $\mathrm{Bu}$ testte farkı mutlak sapmalar kullanılmaktadır. Gözlem birimlerinin grup ortalamalarından, birim medyanından ya da kırpılmış ortalamadan 


\section{T. ÖZKAN- N.I. DURAN - Ö.DEMIRKALE}

farklarının mutlak değerlerine $F$ testi uygulanmasıdır.

$\boldsymbol{W}_{\mathbf{0}}=\left[\sum_{i} \boldsymbol{n}_{i}\left(\bar{Z}_{i}-\bar{Z}\right)^{2} / \sum_{i} \sum_{j}\left(\boldsymbol{Z}_{i j}-\bar{Z}\right)^{2} / \sum_{i}\left(\boldsymbol{n}_{i}-\mathbf{1}\right)\right]$

şeklinde hesaplanmaktadır. Örneklemden elde edilecek istatistik değeri: $Z_{i j}=\left|X_{i j}-\widetilde{X}_{i}\right|, \quad \bar{Z}_{i}=$ $\frac{1}{n_{i}} \sum_{j=1}^{n_{i}} Z_{i j}, \quad \bar{Z}=\frac{1}{N} \sum_{i=1}^{k} \sum_{j=1}^{n_{i}} Z_{i j}$ ile elde edilen

büyüklüklerle hesaplanmaktadır (Güriş vd., 2018, s.75-77).

\section{Otokorelasyon Testi:}

Baltagi Wu (1999) hem sabit etkili hem de tesadüfi etkili panel veri modelleri için kullanılabilen LBI (Yerel En İyi Değişmez Testi) test istatistiğini geliștirmişlerdir. Testin hipotezleri: $H_{o}: \rho=0$, otokorelasyon yoktur.

$$
\text { Alternatif hipotez ise } H_{1}:|\rho|<1 \text {, }
$$

otokorelasyon vardır şeklindedir. Literatürde kritik değerler verilmemesine rağmen değer 2'den küçük ise otokorelasyonun varlığından söz edilmektedir (Güriş vd., 2018, s.83).

\section{Yatay Kesit Bağımlılığının Testi}

Sabit ve rassal etkili modellerde yatay kesit bağımlılığının testi: Pesaran CD testi, standart normal dağılıma sahiptir ve aşağıdaki eşitlikle hesaplanmaktadır. Sıfır hipotezi yatay kesit bağımlılı̆̆ı yoktur, şeklindedir (Güriş vd., 2018, s.88).

$$
C D=\sqrt{\frac{2 T}{N(N-1)}}\left(\sum_{i=1}^{N-1} \sum_{j=i+1}^{N} \rho_{i j}\right)
$$

\section{ANALİZ VE BULGULAR}

Çalışmada ilk olarak 14 çimento şirketi için oluşturulan panel veri modellerinde kullanılacak serilerde birim kökün varlığı araştırılmıştır. Panel birim kök analizine geçmeden önce yatay kesit bağımlılık sınaması yapılmıştır. Yatay kesit bağımlılığının testi Pesaran (2004) CD testiyle incelenebilmektedir. $\mathrm{Bu}$ test için hipotezler aşağıdaki gibidir:

H0: Birimler arasında korelasyon yoktur.

H1: Birimler arasında korelasyon vardır.

Tablo 2: Yatay Kesit Bağımlılık Testi Sonuçları

\begin{tabular}{|l|c|c|}
\hline Değişkenler & CD Test & P değeri \\
\hline SOTS & 73.495 & 0.000 \\
\hline AOTS & 71.426 & 0.000 \\
\hline BOÖS & 44.421 & 0.000 \\
\hline VARL & 64.674 & 0.000 \\
\hline DVAR & 64.918 & 0.000 \\
\hline NAKD & 11.923 & 0.000 \\
\hline SMAL & 68.246 & 0.000 \\
\hline FING & 39.690 & 0.000 \\
\hline FSFB & 17.323 & 0.000 \\
\hline NDKZ & 36.592 & 0.000 \\
\hline FALD & 76.919 & 0.000 \\
\hline KVYK & 61.522 & 0.000 \\
\hline STOK & 64.813 & 0.000 \\
\hline HASILAT & 66.514 & 0.000 \\
\hline TALACAK & 65.760 & 0.000 \\
\hline
\end{tabular}

Tablo 2'den görüldüğü üzere tüm değişkenler için de $\mathrm{p}$ value değeri 0.05 ten küçüktür. Ho reddedilebilir. $\mathrm{Bu}$ nedenle panel birim kök analizi yapılırken yatay kesit bağımlılığını dikkate alan ikinci nesil birim kök testlerinden Pesaran (2004) testinin kullanılması daha uygundur. 14 çimento şirketi için oluşturulan panel veri modelinde kullanılan değișkenlere ait birim kök analiz sonuçları Tablo 3'de yer almaktadır.

Test sonuçlarına göre DVAR, VARL, FALD, AOTS serileri düzeyde durağan, STOK, HASILAT, TALACAK, BOÖS, NAKD, SMAL, FSFB, NDKZ, KVYK, SOTS, FING serileri farkı alınarak durağan hale gelmektedir. Çalışmada serilerin durağan hali kullanılmıştır. Tahmin edilen model, aai değişkeninin bağımlı, satışların ve stokların bağımsız değişken olduğu modeldir. Çalışmada hangi tahmincinin kullanılması gerektiğine karar vermek için Hausman Testi'nden yararlanılmıştır. Sonuçlara Tablo: 4'de yer verilmiştir. 
Tablo 3: Panel Birim Kök Testi Sonuçları

\begin{tabular}{|c|c|c|c|c|c|c|c|c|c|}
\hline SERİ & $\begin{array}{l}\text { DÜZEY } \\
\text { SABİT }\end{array}$ & $\mathbf{P}$ & $\begin{array}{l}\text { DÜZEY } \\
\text { SABİT } \\
\text { TREND }\end{array}$ & $\mathbf{p}$ & $\begin{array}{c}\text { İLK } \\
\text { FARKLAR } \\
\text { SABİT } \\
\end{array}$ & p & $\begin{array}{c}\text { İLK } \\
\text { FARKLAR } \\
\text { TREND } \\
\end{array}$ & $\mathbf{p}$ & Durağanlık \\
\hline STOK & -2.079 & 0.110 & -2.078 & 0.887 & -2.989 & 0.00 & -3.144 & 0.00 & I(1) \\
\hline HASILAT & -2.292 & 0.018 & -2.274 & 0.633 & -2.88 & 0.000 & -3.137 & 0.000 & $\mathrm{I}(1)$ \\
\hline TALACAK & -1.829 & 0.420 & -1.67 & 0.999 & -3.011 & 0.0000 & -3.298 & 0.0000 & I(1) \\
\hline DVAR & -2.595 & 0.000 & -2.626 & 0.000 & -4.232 & 0.000 & -4.546 & 0.000 & $\mathrm{I}(0)$ \\
\hline VARL & -2.327 & 0.000 & -2.407 & 0.000 & -3.337 & 0.000 & -5.079 & 0.000 & $I(0)$ \\
\hline BOÖS & -0.511 & 1.000 & -0.973 & 1.000 & -2.805 & 0.000 & -3.003 & 0.000 & I(1) \\
\hline AOTS & -2.013 & 0.000 & -2.348 & 0.000 & -3.540 & 0.000 & -3.601 & 0.000 & $\mathrm{I}(0)$ \\
\hline NAKD & -2.298 & 0.017 & -2.665 & 0.080 & -5.183 & 0.000 & -4.038 & 0.000 & I(1) \\
\hline SMAL & -1.481 & 0.891 & -1.548 & 1.000 & -2.813 & 0.000 & -2.876 & 0.001 & $\mathrm{I}(\mathbf{1})$ \\
\hline FSFB & -1.819 & 0.437 & -2.839 & 0.015 & -5.845 & 0.000 & -3.755 & 0.000 & I(1) \\
\hline NDKZ & -1.242 & 0.987 & -1.435 & 1.000 & -2.886 & 0.000 & -3.023 & 0.001 & I(1) \\
\hline FALD & -2.270 & 0.022 & -2.590 & 0.143 & -3.565 & 0.000 & -3.609 & 0.000 & $I(0)$ \\
\hline KVYK & -2.029 & 0.153 & -2.256 & 0.662 & -3.885 & 0.000 & -4.143 & 0.000 & I(1) \\
\hline SOTS & -1.877 & 0.345 & -2.505 & 0.246 & -3.299 & 0.000 & -3.343 & 0.000 & $I(1)$ \\
\hline FING & -1.864 & 0.364 & -2.805 & 0.021 & -5.837 & 0.000 & -3.746 & 0.000 & I(1) \\
\hline
\end{tabular}

Tablo 4: Model 1 İçin Hausman Testi

\begin{tabular}{|l|c|c|c|c|}
\hline & B & B & Difference & sqrt \\
\hline stok & -.051515 & -.0462389 & -.0052761 & .0019471 \\
& & & & \\
\hline satış & -.9089716 & -.908285 & -.0006865 & .0003438 \\
& & & & \\
\hline Chi(2) 7.58 Prob>chi2 0.0226 \\
\hline
\end{tabular}

Hausman Testi'nin hipotezleri aşağıdaki gibidir:

Ho: Tesadüfi etkili model geçerlidir.

Ha: Sabit etkili model geçerlidir.

Test sonucuna göre 0.0226 değeri 0.05 ten küçük olduğu için sıfır hipotezi reddedilmektedir. Buna göre sabit etkili modelin varsayımlarının geçerli olduğu, parametreler arasındaki farkın sistematik olduğu ve açıklayıcı değişkenler ile birimler arasında korelasyon olduğu sonucuna varılmaktadır. Sabit Etkili Model'in katsayılarını yorumlamadan önce varsayım sınamaları yapılmıştır. Sabit Etkili Model'in değișen varyans sınaması için Değiştirilmiş Wald Testi kullanılmış ve aşağıdaki hipotezler oluşturulmuştur:

Ho: Sabit varyans varsayımı geçerlidir.

Ha: Değișen varyans varsayımı geçerlidir.

Tablo 5: Wald Testi Sonuçları

$$
\begin{array}{lr}
\text { chi } 2(14)= & 1613.24 \\
\text { Prob }>\text { chi } 2= & 0.0000
\end{array}
$$

Tablo: 5'de yer alan sonuçlara göre "prob" değerinin 0.05 ten küçük olması nedeni ile sıfır hipotezi reddedilmektedir. Varyansın birimlere göre değiștiği görülmektedir. Sabit etkili panel veri modellerinde otokorelasyonun sinanması için ise Baltagi WU LBI Testi kullanılmış, sonuçlarına Tablo: 6'da yer verilmiştir. Testlerin hipotezleri aşağıdadır:

Ho: Otokorelasyon yoktur.

Ha: Otokorelasyon vardır.

Tablo 6: Otokorelasyon Testi Sonuçları

\begin{tabular}{|c|c|}
\hline Durbin Watson & 1.7879414 \\
\hline Baltagi & 1.8104037 \\
\hline
\end{tabular}

Kritik değerler 2'den küçükse otokorelasyonun varlığından söz edilmekte olup, model için otokorelasyon probleminin bulunduğu anlaşılmaktadır. Sabit etkili panel veri modellerinde yatay kesit bağlılığının sınanması için ise Pesaran CD testi kullanılmıştır. Testin hipotezleri Tablo 7'de verilmiştir:

Ho: Yatay kesit bağımlılığı yoktur.

Ha: Yatay kesit bağımlılığı vardır.

Tablo 7: Pesaran CD Testi Sonuçları

\begin{tabular}{|c|c|c|c|}
\hline Test & $\begin{array}{c}\text { Test } \\
\text { İstatistiği }\end{array}$ & $\begin{array}{c}\text { Olasılık } \\
\text { Değeri }\end{array}$ & Sonuç \\
\hline $\begin{array}{c}\text { Pesaran } \\
\text { CD }\end{array}$ & 33.080 & 0.000 & $\begin{array}{c}\text { Yatay kesit } \\
\text { bağımlılığı vardır. }\end{array}$ \\
\hline
\end{tabular}




\section{T. ÖZKAN- N.I. DURAN - Ö.DEMIRKALE}

Modelin değișen varyans, otokorelasyon ve yatay kesit bağımlılık problemi içermesi nedeni ile sapmalı standart hataların yerine dirençli standart hatalara sahip model ile tahmin yapılmıştır. Sonuçlar Tablo: 8'de gösterilmiştir. Tüm katsayılar \%10 düzeyine göre istatistiksel olarak anlamlıdır.

Tablo 8: Robust Standart Hatalar İle Tahmin Sonucu

\begin{tabular}{|c|l|l|l|l|}
\hline $\begin{array}{l}\text { aai } \\
\text { dependent } \\
\text { variable) }\end{array}$ & Katsayı & s.h. & $\mathrm{t}$ & $\mathrm{p}$ \\
\hline stok & -.051515 & .0348952 & -1.48 & 0.100 \\
\hline satış & - & .0138645 & - & 0.000 \\
\hline C & .9089716 & & 65.56 & \\
\hline
\end{tabular}

Modele ait katsayılar dikkate alındığında;

- Hasılat sabit iken, Stok'daki \%1 oranındaki artış SOTS değerini bir önceki çeyreğe göre $\% 0.05$ azaltırken,

- Stok sabit iken, Hasılat'daki \%1 oranındaki artış SOTS değerini bir önceki çeyreğe göre \%0.09 azalttığı anlaşılmaktadır. $\mathrm{Bu}$ sonuç her iki durumda da değișkenler arasında reverse corelation'ın varlığını göstermektedir.

Tablo 9: Adana Bazında Sabit Etki Sonuçları

\begin{tabular}{|l|l|c|}
\hline \multicolumn{1}{|c|}{ Şirket } & \multicolumn{1}{|c|}{ Katsayı Değeri } & Adana'ya Göre Değişim (\%) \\
\hline Afyon & D2: $100 \cdot\left(\mathrm{e}^{\beta}-1\right)=100 \cdot\left(\mathrm{e}^{0.045}-1\right)=200$ & 200 \\
\hline Akçansa & $\mathrm{D} 3: 100 \cdot\left(\mathrm{e}^{-0.052}-1\right)=100 \cdot\left(\mathrm{e}^{-0.052}-1\right)=194$ & 194 \\
\hline Batıçim & $\mathrm{D} 4: 100 \cdot\left(\mathrm{e}^{-0.009}-1\right)=100 \cdot\left(\mathrm{e}^{-0.009}-1\right)=194$ & 199 \\
\hline Bolu & $\mathrm{D} 5: 100 \cdot\left(\mathrm{e}^{-0.036}-1\right)=100 \cdot\left(\mathrm{e}^{-0.036}-1\right)=194$ & 200 \\
\hline Bursa & $\mathrm{D} 6: 100 \cdot\left(\mathrm{e}^{-0.039}-1\right)=100 \cdot\left(\mathrm{e}^{0-0.039}-1\right)=194$ & 198 \\
\hline Çimbeton & $\mathrm{D} 7: 100 \cdot\left(\mathrm{e}^{-0.011}-1\right)=100 \cdot\left(\mathrm{e}^{-0.011}-1\right)=194$ & 192 \\
\hline Çİmentaş & D8: $100 \cdot\left(\mathrm{e}^{-0.077}-1\right)=100 \cdot\left(\mathrm{e}^{-0.077}-1\right)=194$ & 199 \\
\hline Çimsa & $\mathrm{D} 9: 100 \cdot\left(\mathrm{e}^{0.029}-1\right)=100 \cdot\left(\mathrm{e}^{0.029}-1\right)=194$ & 199 \\
\hline Göltaș & $\mathrm{D} 10: 100 \cdot\left(\mathrm{e}^{-0.071}-1\right)=100 \cdot\left(\mathrm{e}^{-0.071}-1\right)=194$ & 199 \\
\hline Konya & $\mathrm{D} 10: 100 \cdot\left(\mathrm{e}^{-0.071}-1\right)=100 \cdot\left(\mathrm{e}^{-0.071}-1\right)=194$ & 200 \\
\hline Lafarge & $\mathrm{D} 12: 100 \cdot\left(\mathrm{e}^{0.022}-1\right)=100 \cdot\left(\mathrm{e}^{0.022}-1\right)=194$ & 201 \\
\hline Mardin & $\mathrm{D} 13: 100 \cdot\left(\mathrm{e}^{0.011}-1\right)=100 \cdot\left(\mathrm{e}^{0.011}-1\right)=194$ & 202 \\
\hline Ünye & $\mathrm{D} 14: 100 \cdot\left(\mathrm{e}^{0.015}-1\right)=100 \cdot\left(\mathrm{e}^{0.015}-1\right)=194$ & \\
\hline
\end{tabular}

İkinci olarak tahmin edilen model ise AOTS değişkeninin bağımlı olduğu, TALC ve HASILAT bağımsız değişsken olduğu modeldir. Çalıșmada hangi tahmincinin kullanılması gerektiğine karar vermek için Hausman Testi
Çimento șirketlerinin sabit etkileri (bağımsız değişkenler sıfır değerini aldığında gerçekleşen ortalama SOTS değeri) Tablo: 8'de yer almaktadır. Değişkenler logaritmik alındığı için Haloversen-Palmquist metodu kullanılmış, katsayı yorumları kukla tuzağına düşmemek için alınan baz çimento şirketi “Adana”ya göre yapılmıştır.

Haloversen - Palmquist metoduna göre nisbi etki $\mathrm{g}=\mathrm{e} \beta-1$ olarak tanımlanırken, yüzde etkisi, $\quad \mathrm{PH}=100$. $\mathrm{g}=100$. (e $\quad \beta-1$ ) olarak tanımlanmaktadır. $\beta$ bilinmeyip, tahmin edilmesi gerektiğinden $\beta, \beta=\ln (1+\mathrm{g})$ 'nin tahmini olarak ele alınmaktadır (Güriş ve Çağlayan; 2011: 376).

Tablo: 8'de yer alan değerler, örneğin; Afyon Çimento şirketi için şöyle yorumlanmalıdır: “Afyon'nun D2 katsayı değeri, 100.( $\left.\mathrm{e}^{\beta}-1\right)=$ 100. $\left(\mathrm{e}^{0.045}-1\right)=200$ 'dür. $\mathrm{Bu}$ değerlerin anlamı; modeldeki diğer bağımsız değişkenler sabit iken, Afyon Çimento şirketinin Adana'ya göre SOTS oranını \%200 oranında artırmakta olduğudur." 
Tablo 10: Model 2 İçin Hausman Testi

\begin{tabular}{|l|c|c|c|c|}
\hline $\begin{array}{l}\text { Bağımlı } \\
\text { değişken: } \\
\text { acp }\end{array}$ & B & \multicolumn{1}{|c|}{ B } & Difference & sqrt \\
\hline TALC & -.5729263 & -.57293 & $3.77 \mathrm{e}-06$ & .0005053 \\
\hline HASILAT & .5637184 & .5637441 & -.0000256 & .0015573 \\
\hline Chi(2) 0.00 Prob>chi2 0.99 & & \\
\hline
\end{tabular}

Tablo: 10 'da yer alan test sonuçlarına göre 0.99 değeri 0.05 ten büyük olduğu için sıfır hipotezi reddedilememektedir. Buna göre Rassal Etkili Model'in varsayımlarının geçerli olduğu anlaşılmaktadır. Rassal Etkili Model'in katsayılarını yorumlamadan önce varsayım sınamaları yapılmıştır. Rassal Etkili Model için değişen varyans sınamasında Değiștirilmiş Wald Testi kullanılmıştır. Testin hipotezleri aşağıdadır:

Ho: Sabit varyans varsayımı geçerlidir.

Ha: Değişen varyans varsayımı geçerlidir.

Tablo 11: Tesadüfi Etkili Model İçin Değișen Varyans Testi Sonucu

\begin{tabular}{|l|c|c|l|}
\hline Varsayımlar & $\begin{array}{c}\text { Test } \\
\text { istatistiği }\end{array}$ & $\begin{array}{c}\text { Olasılık } \\
\text { Değeri }\end{array}$ & \multicolumn{1}{|c|}{ Sonuç } \\
\hline \multirow{2}{*}{$\begin{array}{l}\text { Değişen } \\
\text { varyans } \\
\text { olmama } \\
\text { varsayımı }\end{array}$} & $\mathrm{W} 0=1.715$ & 0.053 & Sabit \\
\cline { 2 - 3 } & $\mathrm{W} 50=0.408$ & 0.968 & varyans \\
\cline { 2 - 3 } & $\mathrm{W} 10=0.999$ & 0.451 & $\begin{array}{l}\text { varsayımı } \\
\text { geçerlidir. }\end{array}$ \\
\hline
\end{tabular}

Tablo 11'de yer verilen sonuçlara göre test istatistiklerine ait prob değerlerinin 0.05 ten büyük olması nedeni ile sıfır hipotezi reddedilememektedir. Sabit varyans varsayımı geçerlidir. Rassal etkili panel veri modellerinde otokorelasyonun sınanması için aşağıda hipotezleri gösterilen Baltagi WU ve Durbin Watson testi kullanılmıştır.

Ho: Otokorealsyon yoktur.

Ha: Otokorealsyon vardır.

Tablo 12: Tesadüfi Etkili Model İçin Otokorelasyon Testi Sonuçları

\begin{tabular}{|l|l|l|l|}
\hline \multicolumn{1}{|c|}{ Test } & $\begin{array}{c}\text { Test } \\
\text { İstatistiği }\end{array}$ & $\begin{array}{c}\text { Olasılık } \\
\text { değeri }\end{array}$ & \multicolumn{1}{c|}{ Sonuç } \\
\hline $\begin{array}{l}\text { Durbin } \\
\text { Watson }\end{array}$ & 1.685 & $1.685 \sim 2$ & $\begin{array}{l}2 \text { testin sonucuna } \\
\text { göre de 1. } \\
\text { dereceden } \\
\text { otokorelasyon } \\
\text { vardır. }\end{array}$ \\
\hline $\begin{array}{l}\text { Baltagi } \\
\text { Wu-LBI }\end{array}$ & 1.696 & $1.696 \sim 2$ \\
\hline
\end{tabular}

Literatürde kritik değerler verilmemesine rağmen değer 2'den küçükse otokorelasyonun varlığından söz edilir. Tablo: 12'ye göre bu model için otokorelasyon problemi mevcuttur. Yatay kesit bağımlılığı testi için Pesaran'ın CD testi yapılmıştır. Tablo: 13'ten görüldügü üzere olasılık değerinin (0.000), 0.05 değerinden küçük olması nedeni ile sıfır hipotezi reddedilmektedir. Sonuca göre yatay kesit bağımlılığı söz konusudur.

Tablo 13: Yatay Kesit Bağımlılı̆̆ı Testi

\begin{tabular}{|l|c|c|l|}
\hline \multicolumn{1}{|c|}{ Test } & $\begin{array}{c}\text { Test } \\
\text { İstatistiği }\end{array}$ & $\begin{array}{c}\text { Olasılık } \\
\text { değeri }\end{array}$ & \multicolumn{1}{c|}{ Sonuç } \\
\hline $\begin{array}{l}\text { Paseran } \\
\text { CD }\end{array}$ & 51.090 & 0.000 & $\begin{array}{l}\text { Yatay kesit } \\
\text { bağımlılığ vardır. }\end{array}$ \\
\hline
\end{tabular}

Modelin otokorelasyon ve yatay kesit bağımlılık problemi içermesi nedeni ile sapmalı standart hataların yerine dirençli standart hatalara sahip model ile tahmin yapılmıştır.

Tablo 14: Robust Standart Hatalar İle Tahmin Sonucu

\begin{tabular}{|c|c|c|c|c|}
\hline \multicolumn{5}{|c|}{$\begin{array}{l}\text { Bağımlı Değişken: acp } \\
\text { Wald Chi(2)=15494 prob }=0.0000\end{array}$} \\
\hline & katsayı & s.h. & $\mathbf{t}$ & $\mathbf{p}$ \\
\hline TALC & .0837 & .0349 & 4.49 & 0.00 \\
\hline Hasılat & -1.038 & .0187 & -124.15 & 0.000 \\
\hline C & .0467 & .0112 & 4.18 & 0.000 \\
\hline
\end{tabular}

Modele ait sabit katsayı yorumları aşağıda verilmiștir.

- Tüm katsayılar $\% 10, \% 5$ ve $\% 1$ anlamlılık düzeyine göre istatistiksel olarak anlamlıdır.

- $\quad$ Wald Testi sonuçlarına göre model genel olarak anlamlıdır. Diğer bir ifade ile modelin genel olarak geçerli olduğu ve tüm katsayılara göre değerlendirme yapılabileceği söylenebilir. - Satışlar sabitken, ticari alacaklardaki $\% 1$ 'lik artış Aots değişkenini \%0.08 artırmaktadır.

- Ticari alacaklar sabitken satışlardaki \%1'lik artış AOTS değişkenini \%1.038 azaltmaktadır.

Üçüncü olarak tahmin edilen model FALD değişkeninin bağımlı olduğu DVAR, FING ve NDKZ'nin bağımsız değişken olduğu modeldir. Çalışmada hangi tahmincinin kullanılması gerektiğine karar vermek için Hausman Testi 
kullanılmıștır. Testin hipotezleri aşağıdaki gibidir:

Ho: Tesadüfi etkili model geçerlidir.

Ha: Sabit etkili model geçerlidir.

Tablo 15: Model 3 İçin Hausman Testi

\begin{tabular}{|l|l|l|l|l|}
\hline $\begin{array}{l}\text { Bağımlı } \\
\text { değişken: } \\
\text { oc }\end{array}$ & B & B & Difference & sqrt \\
\hline DVAR & 0.0830 & .068992 & .0139167 & .0056372 \\
\hline FING & 2.537 & 2.504349 & .0026521 & 0.00000 \\
\hline NDKZ & -0.213 & - & .000122 & 0.0000 \\
\hline $\begin{array}{l}\text { chi2(3)= 5.95 } \\
\text { Prob>chi2 }=\mathbf{0 . 1 1 4 2}\end{array}$ & .2129422 & & \\
\hline
\end{tabular}

Tablo: 15 'de yer alan test sonucuna göre; 0.99 değeri 0.05 ten büyük olduğu için sıfır hipotezi reddedilememekte olup, rassal etkili modelin varsayımlarının geçerli olduğu anlaşılmaktadır. Buna göre parametreler arasındaki farkın sistematik olmadığı ve birim etkileri ile açıklayıcı değişkenler arasında korelasyon bulunmadığı sonucuna ulaşılmaktadır. Rassal etkili modelin katsayıları yorumlanmadan önce varsayım sınamaları yapılmış ve modelin değișen varyans sınaması için Değiştirilmiş Wald Testi kullanılmıştır. Wald testi için hipotezler aşağıdaki gibidir:

Ho: Sabit varyans varsayımı geçerlidir.

Ha: Değişen varyans varsayımı geçerlidir.

Tablo 16: Tesadüfi Etkili Model için Değișen Varyans Testi Sonucu

\begin{tabular}{|l|l|l|l|}
\hline Varsayımlar & $\begin{array}{l}\text { Test } \\
\text { istatistiği }\end{array}$ & $\begin{array}{c}\text { Olasılık } \\
\text { Değeri }\end{array}$ & Sonuç \\
\hline $\begin{array}{l}\text { Değişen } \\
\text { varyans } \\
\text { olmama } \\
\text { varsayımı }\end{array}$ & $\mathrm{W} 0=2.710$ & 0.00088251 & $\begin{array}{l}\text { Sabit } \\
\text { varyans } \\
\text { varsayımı } \\
\text { geçerlidir. }\end{array}$ \\
\cline { 2 - 3 } & $\mathrm{W} 50=2.234$ & 0.00691035 & \\
\cline { 2 - 3 } & $\mathrm{W} 10=2.483$ & 0.00239836 & \\
\hline
\end{tabular}

Tablo:16 sonuçlarına göre test istatistiklerine ait prob değerlerinin 0.05 ten küçük olması nedeni ile sıfır hipotezi reddedilmektedir. Modelde değişen varyans söz konusudur. Rassal etkili panel veri modellerinde otokorelasyonun sınanması için Baltagi WU ve Durbin Watson testi kullanılmıştır. Testlerin hipotezleri aşağıdadır:

Ho: Otokorelasyon yoktur.
Ha: Otokorelasyon vardır.

Tablo 17: Tesadüfi etkili model için otokorelasyon testi sonuçları

\begin{tabular}{|l|l|l|}
\hline Test & $\begin{array}{l}\text { Test } \\
\text { İstatistiği }\end{array}$ & Sonuç \\
\hline $\begin{array}{l}\text { Durbin } \\
\text { Watson }\end{array}$ & 2.0660438 & $\begin{array}{l}\text { 2 testin sonucuna göre de } \\
\text { 1. dereceden } \\
\text { otokorelasyon yoktur. }\end{array}$ \\
\hline $\begin{array}{l}\text { Baltagi Wu- } \\
\text { LBI }\end{array}$ & 2.0860688 & \\
\hline
\end{tabular}

Literatürde kritik değerler verilmemesine rağmen, Tablo: 17'deki değerlerin 2'ye yakın olması modelde otokorelasyon problemi olmadığını göstermektedir. Yatay kesit bağımlılığı testi için Pesaran in CD testi yapılmıştır. Tablo: 17'deki sonuca göre yatay kesit bağımlılığı söz konusudur.

Tablo 18: Yatay Kesit Bağımlılık Testi

\begin{tabular}{|l|c|c|l|}
\hline Test & $\begin{array}{l}\text { Test } \\
\text { İstatistiği }\end{array}$ & $\begin{array}{l}\text { Olasılık } \\
\text { değeri }\end{array}$ & Sonuç \\
\hline $\begin{array}{l}\text { Paseran } \\
\text { CD }\end{array}$ & 71.834 & 0.000 & $\begin{array}{l}\text { Yatay kesit } \\
\text { bağımlılığı vardır. }\end{array}$ \\
\hline
\end{tabular}

Modelin değișen varyans ve yatay kesit bağımlılık problemi içermesi nedeni ile sapmalı standart hataların yerine dirençli standart hatalara sahip model ile tahmin yapılmıştır.

Tablo 19: Robust Panel Veri Modeli

\begin{tabular}{|l|c|c|c|c|}
\hline \multicolumn{4}{|l|}{ Bağı̆ml Değişken: oc } \\
Wald Chi(2)= 8.79 prob= 0.032 \\
\hline & katsayı & sh & t & p \\
\hline DVAR & .068992 & .0309715 & 2.23 & 0.026 \\
\hline FING & 2.504349 & 1.728645 & 1.45 & 0.147 \\
\hline NDKZ & -.2129422 & .1691099 & -1.26 & $0.208^{*}$ \\
\hline c & 4.179534 & .5776809 & .7 .24 & 0.000 \\
\hline
\end{tabular}

Tablo: 19'da NDKZ değerinin istatistiksel olarak anlamsız çıkması nedeniyle değişken modelden atılarak model tekrar tahmin edilmiştir.

Tablo 20: Robust Standart Hatalar İle Tahmin Sonucu

\begin{tabular}{|l|c|c|c|c|}
\hline \multicolumn{4}{|l|}{$\begin{array}{l}\text { Bağımlı Değişken: oc } \\
\text { Wald Chi(2)= } 6.59 \text { prob }=0.0371\end{array}$} \\
\hline & katsayı & s.h. & t & p \\
\hline DVAR & .0668814 & .0310333 & 2.16 & 0.031 \\
\hline FING & 2.068085 & 1.265795 & 1.63 & 0.102 \\
\hline c & 4.215535 & .5783206 & 7.29 & 0.000 \\
\hline
\end{tabular}

Tablo: 20'deki Modele ait sabit katsayı yorumları aşağıda verilmiştir: 
- $\quad$ Tüm katsaylar $\% 10, \% 5$ ve $\% 1$ anlamlılık düzeyine göre istatistiksel olarak anlamlıdır.

- $\quad$ Modelin genel olarak geçerli olduğu ve tüm katsayılara göre değerlendirme yapılabileceği söylenebilir.

- $\quad$ FING sabitken, DVAR'daki \%1'lik artış FALD değişkenini \%0.066 arttırmaktadır.

- $\quad$ DVAR sabitken FING'deki \%1'lik artış FALD değişkenini \%2.068 arttırmaktadır.

BOÖS değişkeninin bağımlı, KVYK ve SMAL'ın bağımsız değişken olduğu dördüncü tahmin edilen modelde katsayılar anlamsız çıkmıştır. Beşinci tahmin edilen model FING değişkeninin bağımlı olduğu SOTS ve BOÖS'nin bağımsız değişken olduğu model olup, NDKZ'ın SOTS, AOTS ve BOÖS ile ilişkisine bakıldığında, AOTS anlamlı çıkmamıştır. Hangi tahmincinin kullanılması gerektiğine karar vermek için Hausman Testi'nden yararlanılmıștır. Hausman Testi'nin hipotezleri aşağıdaki gibidir:

Ho: Tesadüfi etkili model geçerlidir.

Ha: Sabit etkili model geçerlidir.

Tablo 21: Model 5 için Hausman Testi

\begin{tabular}{|l|l|l|l|l|}
\hline $\begin{array}{l}\text { Bağımlı } \\
\text { değişken: } \\
\text { finex }\end{array}$ & $\mathrm{b}$ & $\mathrm{B}$ & Difference & Sqrt \\
\hline SOTS & .0088951 & .0089241 & -.000029 & .0018276 \\
\hline BOÖS & -.0056331 & -.0056579 & .0000248 & .0001743 \\
\hline $\begin{array}{l}\text { chi2(3)= 0.02 } \\
\text { Prob>chi2 }=\mathbf{0 . 9 8}\end{array}$ \\
\hline
\end{tabular}

Tablo: 21'de belirtilen verilere göre; rassal etkili modelin varsayımlarının geçerli olduğu anlaşılmaktadır. Parametreler arasındaki farkın sistematik olmadığı ve birim etkileri ile açıklayıcı değişkenler arasında korelasyon bulunmadığı sonucuna ulaşılmaktadır. Rassal etkili modelin katsayıları yorumlamadan önce varsayım sınamaları yapılmış, Değiştirilmiş Wald Testi kullanılmıştır. Testin hipotezleri aşağıdadır:

Ho: Sabit varyans varsayımı geçerlidir.

Ha: Değişen varyans varsayımı geçerlidir.

Tablo: 21'de belirtilen veriler dikkate alındığında; değișen varyans testi sonuçlarına göre, test istatistiklerine ait prob değerlerinin 0.05 'ten küçük olması nedeni ile sıfır hipotezi reddedilmektedir. Modelde değișen varyans söz konusudur.

Tablo 22: Tesadüfi Etkili Model İçin Değișen Varyans Testi Sonucu

\begin{tabular}{|l|l|l|l|}
\hline Varsayımlar & $\begin{array}{l}\text { Test } \\
\text { istatistiği }\end{array}$ & $\begin{array}{l}\text { Olasılık } \\
\text { Değeri }\end{array}$ & Sonuç \\
\hline Değişen & W0= 3.529 & & Sabit \\
varyans & & 0.00001915 & varyans \\
olmama & varsayımı \\
varsayımı & 1.822 & 0.03538043 & geçerlidir. \\
& W10= & & \\
\cline { 2 - 3 } & 1.827 & 0.0346593 & \\
\hline
\end{tabular}

Rassal etkili panel veri modellerinde otokorelasyonun sınanması için ise Baltagi WU ve Durbin Watson testi kullanılmıştır. Tablo: 22'den anlaşıldığ gibi; Durbin Watson istatistiğine göre modelde 1 . dereceden otokorelasyon mevcuttur. Testlerin hipotezleri aşağıdadır:

Ho: Otokorelasyon yoktur.

Ha: Otokorelasyon vardır.

Tablo 23: Tesadüfi Etkili Model için Otokorelasyon Testi Sonuçları

\begin{tabular}{|c|c|c|}
\hline Test & $\begin{array}{l}\text { Test } \\
\text { İstatistiği }\end{array}$ & Sonuç \\
\hline $\begin{array}{l}\text { Durbin } \\
\text { Watson }\end{array}$ & 1.0855201 & \multirow{2}{*}{$\begin{array}{l}\text { Durbin Watson } \\
\text { istatistiğine göre } 1 . \\
\text { dereceden otokorelasyon } \\
\text { mevcuttur. }\end{array}$} \\
\hline $\begin{array}{l}\text { Baltagi Wu- } \\
\text { LBI }\end{array}$ & 1.9966955 & \\
\hline
\end{tabular}

Yatay kesit bağımlılığı testi için Pesaran in CD testi yapılmıştır. Tablo: 23 verilerine göre, yatay kesit bağımlılığı söz konusudur.

Tablo 24: Yatay Kesit Bağımlılık Testi

\begin{tabular}{|l|c|c|l|}
\hline Test & $\begin{array}{l}\text { Test } \\
\text { İstatistiği }\end{array}$ & $\begin{array}{l}\text { Olasılık } \\
\text { değeri }\end{array}$ & Sonuç \\
\hline $\begin{array}{l}\text { Paseran } \\
\text { CD }\end{array}$ & 21.919 & 0.000 & $\begin{array}{l}\text { Yatay kesit } \\
\text { bağımlılı̆ı vardır. }\end{array}$ \\
\hline
\end{tabular}

Modelin değişen varyans ve yatay kesit bağımlılık problemi içermesi nedeni ile sapmalı standart hataların yerine dirençli standart hatalara sahip model ile tahmin yapılmıştır. Modele ait sabit katsayı yorumları aşağıdadır (Tablo 25):

- Tüm katsayılar \%10 anlamlılık düzeyine göre istatistiksel olarak anlamlıdır.

- Wald Testi sonuçlarına bakıldığında model genel olarak anlamlı olup, modelin genel 


\section{T. ÖZKAN- N.I. DURAN - Ö.DEMIRKALE}

olarak geçerli olduğu ve tüm katsayılara göre değerlendirme yapılabileceği söylenebilir.

- $\quad$ SOTS sabitken, BOÖS'deki \%1'lik artış FING değişkenini \%0.005 azaltmaktadır.

- $\quad$ BOÖS sabitken SOTS'deki i \%1'lik artış FING değișkenini \%0.0089 arttırmaktadır.

Tablo 25: Robust Standart Hatalar İle Tahmin Sonucu

\begin{tabular}{|c|c|c|c|c|}
\hline \multicolumn{5}{|c|}{$\begin{array}{l}\text { Bağımlı Değişken: fnex } \\
\text { Wald Chi(2)= } 8.41 \text { prob }=0.0149\end{array}$} \\
\hline & katsayı & sh & $\mathbf{t}$ & $\mathbf{p}$ \\
\hline SOTS & .0089241 & .0042905 & 2.08 & 0.038 \\
\hline BOÖS & -.0056579 & .0032195 & -1.76 & 0.079 \\
\hline $\mathrm{C}$ & -.0012652 & .0007683 & -1.65 & 0.100 \\
\hline
\end{tabular}

\section{SONUÇ}

Bu çalışma Türkiye'de faaliyet gösteren ve pay senetleri BISST'de işlem gören on dört çimento şirketinin 1997-2018 yıllarının üçer aylık dönemlerini ve finansal verilerini kapsamaktadır. $\mathrm{Bu}$ amaçla öncelikle çimento şirketlerinin 1997-2018 dönemleri arasında bilanço ve gelir tabloları kullanılarak faaliyet ve nakit döngüleri hesaplanmıştır. Daha sonra her iki döngünün belirlenen performans kalemleri üzerine etkileri panel veri analizi yöntemiyle incelenmiştir.

Çıkan sonuçlara göre, stoklar ve satışların, stokların ortalama tüketilme süresi üzerinde istatistiksel olarak anlamlı bir etkisi olduğu tespit edilmiştir. Her iki değişken ile stokların ortalama tüketilme süresi arasındaki ilişki ters yönlüdür. Birim etkileri incelendiğinde ise Çimentaş şirketinin Adana Çimento şirketine göre stokların ortalama tüketilme süresi üzerindeki etkisinin en düşük yüzdeye sahip olduğu belirlenirken, yine Adana Çimento şirketine göre en yüksek yüzdenin Ünye Çimento'ya ait olduğu görülmektedir. Buna ek olarak, ilgili dönemde, ortalama tahsil süresi ile ticari alacaklar ve satışlar arasında istatistiksel olarak anlamlı bir ilişki tespit edilmiştir. Analiz sonuçlarına göre, ortalama tahsil süresi ile ticari alacakların aynı yönlü ilişkiye sahip olduğu belirlenirken, satışların negatif ilişki özelliği gösterdiği anlaşılmıştır.

Yapılan tahminler sonucunda, işletme döngüsü ile dönen varlıklar ve finansman giderleri değișkenleri arasında istatistiksel olarak anlamlı bir ilişki bulunmuștur. Dönen varlıklar ve finansman giderleri değișkenlerinin her ikisinin de işletme döngüsü üzerindeki etkisi pozitif yönlüdür. Bunun yanı sıra, stokların ortalama tüketilme süresi ve borçların ortalama ödeme süresi ile finansman giderleri arasında istatistiksel olarak anlamlı bir ilişki bulunmuştur. Borçların ortalama ödeme süresi ile finansman giderleri arasındaki ilişkinin ters yönlü olduğu belirlenirken, stokların ortalama tüketilme süresi ile finansman giderleri arasındaki ilişkinin aynı yönlü olduğu tespit edilmiştir.

Faaliyet ve nakit döngüsünün finansal performans üzerinde etkilerini inceleyen çalışmanın diğer bir sonucu da, ilgili dönemde, varlıklar, finansal yükümlülükler değişkenlerinin yapılan tüm tahminlerde istatistiksel olarak anlamsız çıkmasıdır. Net dönem kârı değişkeni ise, bir modelde anlamlı sonuç vermesine rağmen, ilgili modelde varsayımları sağlamaması nedeni ile yapılan robust tahmini sonucunda istatistiksel olarak anlamsız bulunmuş ve bu nedenle modelden çıkarılmıştır. Elde edilen tüm bu bulgular sonucunda, ilgili değişkenlerle yapılan tahminlerin sonuçlarına ve yorumlamalarına çalışmada yer verilmemiştir.

Özellikle fiziki üretim yapan bir işletmede girdilerin stoklara alınması ve üretim evresi de dâhil olmak üzere nihai ürünlerin gerek nakdi gerekse vadeli olarak satıldığı tüm süreç faaliyet döngüsünü oluşturmaktadır. Nakit döngüsü ise tahsilat ile borçların ödeme sürelerini kapsayan nakit akışlarını tanımlamaktadır. Faaliyet ve nakit döngüleri baz alınarak yapılan çalışmamızda; işletme döngüsünü duran varlıkların ve finansal giderlerin etkilediği, alacakların ortalama tahsil süresinin ve borçların ortalama ödeme süresinin finansal giderler üzerinde istatistiksel olarak anlamlı bir etkiye sahip olduğu görülmüştür. 


\section{KAYNAKÇA}

Attari, M.A., Raza, K. (2012). The Optimal Relationship of Cash Conversion Cycle with Firm Size and Profitability, International Journal of Academic Research in Business and Social Sciences, Vol. 2, No: 4.

Çakır, H.M. (2013). Nakit Döngüsünün Firma Kârlılığına Etkisinin Sektörel Analizi, Journal of Yaşar University, Vol. 30, No:8, 4948-4965.

Dorisz, T., Andrea, R. (2015). Financial Competitiveness Analysis in the Hungarian Dairy Industry, Competitiveness Review, Vol. 25, Issue: 4.

Ebben J.J., Johnson, A.C. (2011). Cash Conversion Cycle Management in Small Firms: Relationships with Liquidity, Invested Capital and Firm Performance, Journal of Small Business and Enterpreneurship, Vol. 24, No: 3.

Farris, M.T., Hutchison P.D., Hasty, R.W. (2005). Using Cash-to-Cash to Benchmark Service Industry Performance, Journal of Applied Business Research, Vol. 21, No:2.

Gill, A., Biger, N., Obradovich, J. (2014). The Impact of Independent Directors on the Cash Conversion Cycle of American Manufacturing Firms, International Journal of Economics and Finance, Vol. 7, No: 1.

Karadeniz, E. (2012). Turizm Sektörünün Nakit Döüşüm Süresinin Analizi: İMKB Turizm Şirketleri ve TCMB Sektör Bilançoları Üzerinde Bir Araştırma, Çağ University Journal of Social Sciences, Vol. 9, No: 1.

Korkmaz, T., Uygurtürk, H., Gökbulut, R.İ., Güğerçin, G. (2008). Marmara Üniversitesi, İIBF Dergisi, Cilt: XXV, Sayı: 2.

Lyngstadaas, H., Berg, T (2016). Working Capital management: Evidence from Norway, International Journal of Managerial Finance, Vol. 12, Issue: 3.

Mathuva, D.M. (2014). An Empirical Analysis of the Determinants of the Cash Conversion Cycle in Kenyan Listed Non-Financial Firms, Journal of Accounting in Emerging Economies, Vol. 4, Issue: 2.

Mohama N. A. B., \& Saad, N.B.M. (2010). Working Capital Management: The Effect of Market Valuation and Profitability in Malaysia, International Journal of Business and Management, Vol. 5, No. 11.

Nobanee, H., Abdullatif, M., AlHAjjar, M. (2011). Cash Conversion Cycle and Firm's Performance of Japanese Firms, Asian Review of Accounting, Vol. 19, Issue: 2.

Ramachandran:, A, Janakiraman, M (2009). Managing Global Transitions: International Research Journal, Vol. 7, Issue:1.

Sakarya, Ş. (2008). Nakit Yönetiminde Nakit Dönüş Süresi Analizinin Kullanılması: IMKB'deki KOBİ'ler Üzerinde Ampirik Bir Çalışma, Süleyman Demirel Üniversitesi, İktisadi ve İdari Bilimler Fakültesi dergisi, Vol. 113, No: 2.

Talonpoika, A.M., Monto, S., Pirttila, M., Karri, T. (2014). Modifying the Cash Conversion Cycle: Revealing Concealed Advance Payments, International Journal of Productivity and Performance Management, Vol. 63, Issue: 3.

Teruel, P.J.G., Solano, P.M. (2007). Effects of Working Capital Management on SME Profitability, International Journal of Managerial Finance, Vol. 3, Issue: 2.

Tusek, B., Percevic, H, Hladika, M. (2014) Interdependence Between Cash Gap and Profitability in the Hotel Industry in Croatia, Acta Turistica, Faculty o Economics and Business, University of Zagrep, Vol. 26, No: 1.

Yazdanfar, D., Öhman, P. (2014). The Impact of Cash Conversion Cycle ob Firm Profitability, International Journal of Managerial Finance, Vol. 10, Issue: 4.

www.kap.gov.tr 